\title{
Rethinking Hanslick?
}

\section{Gómez AG*}

Universidad Michoacana de San Nicolás de Hidalgo, México

\section{Research Article}

Volume 2 Special Issue 1

Received Date: October 18, 2019

Published Date: November 08, 2019

DOI: $10.23880 /$ phij-16000S1-001

Nicolás de Hidalgo, Santiago Tapia 403, Morelia 58000, Michoacán, México; Email: artuchik@yahoo.com

\section{Abstract}

As an answer to the main question: can art communicate knowledge? proposed by Philosophy International Journal to a special issue: Art and Knowledge, this article briefly debates about the old dichotomy between two antagonistic conceptions of music. On one hand, the Kantian-Hanslickian formal aesthetic theory that conceives music like an ornamental art, like a beautiful play of sensations denying content in music, and on the other hand, the romanticidealistic Aesthetics and the subsequent Marxist-realist conceptions, that consider music like a language capable to communicate knowledge.

Keywords: Artistic knowledge; Artistic model; Musical form; Intonation

Can music communicate knowledge? This question is more than two hundred and fifty years old. In the age of Enlightenment, many critics and writers discussed the content of music and how it communicates. This question became acute in the $18^{\text {th }}$ century as the instrumental genres began to break away from their humble origins in, for the most part, dance music, and to take on an independent expressive role.

While the Baroque composers certainly created an immense corpus of purely instrumental music, it only started to take on what we might discern as a personality with the music of Joseph Haydn and Wolfgang A. Mozart. Movements from symphonies or string quartets lost their abstract character and began to reflect a whole spectrum of quirky human individuality.

It may have been an inkling of this that led the famous outburst of the French writer Bernard Le Bovier de Fontenelle: "Sonate, que me veux tu? » [Sonata, what do you want from me?], cited by Jean-Jacques Rousseau at the end of his article about 'Sonate' in the Encyclopédie. This remark was mentioned many times in the $18^{\text {th }}$ century in connection with the controversy over the problem of the meaning or nature of expression in instrumental music.

The frequency of approving citations of Fontenelle's famous question rejects the degree of perplexity which met the idea of purely instrumental music in eighteenthcentury French musical writings. Although the expressive qualities of such music were rarely denied tout-court, for a century whose pursuit of signs followed an almost exclusively positive conception, the question of what instrumental music signed permitted of no easy answers.

For this reason, theoretical interest in the aesthetics of instrumental music was almost completely overshadowed by the enormous quantity of material devoted to vocal and theatrical music. The contributions to music theory by the philosopher Jean-Jacques Rousseau are often 


\section{Philosophy International Journal}

placed in association with this suspicion of 'emptiness' of instrumental music ${ }^{1}$.

At the end of the Enlightenment the Transcendental Philosophy of Immanuel Kant produced a turn in the Aesthetics of music. In the first part of his Critique of Judgment (1790), Kant affirms that the objective of the aesthetic Judgement is the Beauty; the Beauty not like a real property of things, but like something that emerges from the relationship between the object and the subject. Therefore, for Kant the fundaments of the aesthetic Judgement are in the free play and harmony of our spiritual faculties that the object produces in the subject. The Beauty is that harmony between Imagination and Understanding that expresses in aesthetical Ideas.

In the paragraph 51. Of the division of the beautiful arts, Kant describes music like the art of the beautiful play of sensations externally stimulated, "which admits at the same time of universal communication, can be concerned with nothing else than the proportion of the different degrees of the disposition (tension) of the sense, to which the sensation belongs, i. e. with its tone" ${ }^{2}$. The music is the art of free play of sensations of hearing as external sensible impressions.

[...] we cannot say with certainty whether colours or tones (sounds) are merely pleasant sensations or whether they form in themselves a beautiful play or sensations, and as such bring with them in aesthetical judgment a satisfaction in their form. [...] both kinds of sensations are to be regarded not as mere sensible impressions, but as the effects of a judgment passed upon the form in the play of diverse sensations. The difference in our definition, according as we adopt the one or the other option in judging of the grounds of Music, would be just this: [...] we must explain it as the beautiful play of sensations (of hearing), or else as a play of pleasant sensations ${ }^{3}$.

For Immanuel Kant musical art was more pleasure than culture. Music is free beauty and means nothing by itself. The musical phantasies or all music without words represents nothing, there is no object under a definite concept. Therefore, music had the lowest place among the beautiful arts because it was valued merely for its pleasantness.

${ }^{1}$ Cf. Guy Dammann. “ «Sonate, que me veux-tu? »: Jean-Jacques Rousseau and the Problem of Instrumental Music" Ad Parnassum, Vol. 3, № 5, 2005:57-67, p. 57.

${ }^{2}$ Kant's Critique of Judgment. Translated by J. H. Bernard. Macmillan, London, 1914, p. 212.

${ }^{3}$ Kant's Critique of Judgment, pp. 212-213.
In fact, Kant's musical judgments were very regrettable. His biographers affirm that he never lefts Königsberg, a small City isolated from the exuberant musical culture of the great European capitals, like Wien. About his musical judgment we quote two fragments:

Even the song of birds, which we can bring under no musical rule, seems to have more freedom, and therefore more for taste, tan a song of a human being which is produced in accordance with all the rules of music; for we very much sooner weary of the latter, if it is repeated often and at length. [...] Pleasant arts are those that are directed merely to enjoyment. [...] Among these are also to be reckoned the way of arranging the table for enjoyment, and, at great feasts, the management of the music. This letter is a wonderful thing. It is meant to dispose to gaiety the minds of the guests, regarded solely as a pleasant noise, without anyone paying the least attention to its composition ${ }^{4}$.

It is evident that for Immanuel Kant music was only a decorative art without content, or even worse, a simple pleasant noise merely for enjoyment. Nevertheless, the Kantian conception of music had a great influence in the musical Aesthetics of $19^{\text {th }}$ Century.

In 1854 the Austrian critic Eduard Hanslick published in Leipzig his seminal book about music aesthetics The Beautiful in Music [Vom Musikalisch-Schönen: Ein Beitrag zur Revision der Ästhetik der Tonkunst]. This small book elicited controversy and heated debate. It was directed against the aesthetics of feeling prevalent in the eighteenth and nineteenth centuries writings on music. The issues that had provoked most controversy was to speak about a lack of content in instrumental music and denied the emotions as a source of knowledge. In the seventh chapter of this book, that begins with the question: "Has Music any subject?", Hanslick mentions Immanuel Kant among those philosophers who sustained that music has no subject.

Has Music any subject? This has been a burning question ever since people began to reflect upon music. Is has been answered both in the affirmative and in the negative. Many prominent men, almost exclusively philosophers, among whom we may mention Rousseau, Kant, Hegel, Herbart, Kahlert, \&c., hold that music has not subject. [...] Those who contend that music has a subject are numerically far stronger: among them are the trained musicians of the literary profession, and their convictions are shared by the bulk of the public. [...] many of these

\footnotetext{
${ }^{4}$ Kant's Critique of Judgment, pp. 100, 186.
} 


\section{Philosophy International Journal}

musical authors are more anxious to save the so-called honor of their art than ascertain the truth. They attack the doctrine that music has no subject, not as one opinion against another, but as heresy against dogma ${ }^{5}$.

Hanslick affirms that the indiscriminate use of the terms, such like 'content', 'subject' or 'matter', is responsible for all this ambiguity: "the same meaning being expressed by different terms, or the same term associated with different meaning", and sustains that content, "in the true and original sense, is that which a thing contains, what it holds within". So, for Hanslick only "the notes of which a piece of music is composed, and which are the parts that go to make up the whole, are the contents in this sense" 6 .

Just like Kantian 'beautiful play of sensations', Hanslick affirms that music is unable to express emotions and feelings. In his argument, following the aesthetic theory of mimesis (Du Bos, Batteaux and Lessing), Hanslick states that unlike figurative arts, music does not have a model or an object of imitation in Nature.

On examining in what sense Nature provides music with its material, we find that she supplies nothing but the rough elements, from which man contrives to elicit sounds. [...] the raw material with which the musical note is formed. [...] therefore, we are furnished only with material for the production of material, that is, of sound of high or low pitch; [...] the primary and essential condition of all music, whose function it is to so combine these tones as to produce melody and harmony, its two main factors. Neither of them is provided for us by Mature ready made, but both are creations of the human mind?

In his formal conception of music, like the device of the beautiful combination of sounds, Hanslick not only excludes Nature from music but even excludes human Nature, the soul, the language, the culture, the social life, and the history. His rationalistic conception takes him to visualize music to an external space like an acoustic phenomenon, searching in Nature that he could have found in the human being. He repetitively affirms that music has no content, therefore he was forced to used visual images to explain music, with his famous arabesque and kaleidoscope.

\footnotetext{
5Eduard Hanslick. The Beautiful in Music. A contribution to the revisal of musical Aesthetics. London: Novello, 1891, pp. 160-61.

${ }^{6}$ Hanslick, The Beautiful in Music, p. 161.

${ }^{7}$ Hanslick, The Beautiful in Music, p. 144.
}

So far we have considered only the negative aspect of the question, and have sought to expose the fallacy that the beautiful in music depends upon the accurate expression of feelings. We must now [...] to determinate of what nature the beautiful in music is. Its nature is specifically musical. [...] The primordial element of music is euphony, and rhythm is its soul. [...] Melody. [...] Harmony. [...] To the question what is to be expressed with all this material? the answer will be: musical ideas. Now, a musical idea, reproduced in its entirety, is not only an object of intrinsic beauty, but also an end in itself, and not a means for representing feelings and thoughts. The essence of music is sound and motion. The arabesque [..] in what manner music may exhibit forms of beauty, though no definite emotion be involved. [...] Now, music is a kind of kaleidoscope, though its forms can be appreciated only by an infinitely higher ideation ${ }^{8}$.

Heritress of Kantian formalism (based on conceptual similarities between Critique of Judgment and The Beautiful in Music), certainly Hanslick's Aesthetics emerge from Viennese liberalism, which also shares common traits with European Positivism of the time such as the belief in progress and the promotion of scientific methods. ${ }^{9}$ This work had an enormous influence on musical life and musicology of the $20^{\text {th }}$ century. Since the publication of this Büchlein, the discussion on musical aesthetics tended to binary oppositions: form/ expression; absolute/ program music; objectivity/ subjectivity; formalism/ hermeneutic criticism.

The initial public reaction to Hanslick Büchlein came from the so-called New German School of Wagner and Liszt. Franz Liszt staked out his leading role within the opposition to Hanslick. In 1855 was published in five installments his aesthetic manifesto, Berlioz und seine Haroldsymphonie, in the Neue Zeitschrift für Musik ${ }^{10}$.

The document is dedicated to the Symphony of Hector Berlioz 'Harold en Italie' composed in 1834. In his defense of the instrumental music on a concrete subject, the so-

\footnotetext{
${ }^{8}$ Hanslick, The Beautiful in Music, pp. 66-68.

${ }_{9}^{9}$ About the Kantian influence on Hanslick there are several works. For example, Alexander Wilfing sustains that Hanslick's Philosophical Background was indeed the aesthetic formalism of Johann F. Herbart. In: "Hanslick, Kant, and the origins of Vom Musikalisch-Schönen" Musicologica Austriaca - Journal of Austrian Music Studies, 2018.

${ }^{10}$ Franz Liszt. "Berlioz und seine Haroldsymphonie" Neue Zeitschrift für Musik, Band 43, Juli bis Dezember 1855: № 3 (Den 13 Juli): 2532; № 4 (Den 20 Juli): 37-46; № 5 (Den 27 Juli): 49-55; № 8 (Den 17 August): 77-84; und № 9 (Den 24 August): 89-97. The text is a translation into German, by Richard Pohl, from the French original of Liszt and the Princess Wittgenstein.
} 


\section{Philosophy International Journal}

called program music, Liszt affirms that music embodies feeling and combine it with thought.

If music has one advantage over the other means through which man can reproduce the impressions of his soul, it owes this to its supreme capacity to make each inner impulse audible without the assistance of reason, so restricted in the diversity of its forms, capable, after all, only of conforming or describing our affections, not of communicating them directly in their full intensity, in that to accomplish this even approximately it is obliged to search for images and comparisons ${ }^{11}$.

Music presents the intensity and the expression of feeling; it is the embodied and intelligible essence of feeling. Quoting Hegel's Ästhetik, Liszt writes that music is spirit or soul, sounding without mediation for itself alone and finding satisfaction in its self-recognition.

Music is the language of the soul. [...] The special task of music is that, in presenting any content to the mind, it presents it neither as it is latent in consciousness as a general concept, nor as definite external form offers itself elsewhere to observation or is through art more completely represented, but rather in the way in which it becomes alive in the sphere of subjective inwardness ${ }^{12}$.

The public reaction to Hanslick treatise Vom Musikalisch-Schönen continued in Russia. In 1880 the book was translated for the first time in the journal Русская Мысль [Russkaya Mysl - Russian Thought] ${ }^{13}$. Then, in 1895 it was published by Peter Jürgenson in Moscow $^{14}$. In the foreword to the first translation, the editor Sergey Yuryev writes:

[...] the artistic beauty is a result of especial act of creation of human spirit, a product of movement and activity of the deepest and fundamental spiritual powers. That's way is impossible to agree with the author that the study on Beauty will improve with the scientific method. [...] He will complete his task even more, if he explains the concept of artistic contemplation which he so abruptly separated from feelings [...] Just like we cannot agree with the author that the old Aesthetics, like he calls it, selected

\footnotetext{
${ }^{11}$ Liszt, "Berlioz und seine Haroldsymphonie" Neue Zeitschrift für Musik, № 4 (Den 20 Juli 1855), S. 40-41.

12Ibídem. Hegels Ästhetik, III, iii, 2.

13Эдуард Ганслик. «0 прекрасномъ въ музыке» Русская Мысль, кн. XI, 1880.

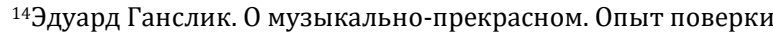
музыкальной эстетики. Перевод с немецкого Г. А. Лароша. Москва, Изд. П. Юргенсона, 1895.
}

Beauty only in relation with the impression provoked by it, and that previous researches on Beauty have not the conviction that the Beauty laws of each art emerged from the characteristics of its material ${ }^{15}$.

In this preface, Sergey Yuryev affirmed that as well as in the research of the psychic act, called artistic contemplation, stands out the aesthetic aspect from all other aspects of the object. The same power of excitation of this psychic act consists of the inseparable element of the beautiful life that, above all, we must determine the properties and essence of artistic contemplation in general, and particularly the strengths of its excitation.

In general, Hanslick's Büchlein it was not well received in Russia. Critics and writers like Alexandr Serov or Vladimir Stasov were involved in the aesthetic-romantic principles of Wagner and Liszt. For them, art was, above all, a reflection of life, and the most important was the discovery of the emotional content in music. For Russian culture, music was, in essence, the expression of life itself. This principle was valid for musical interpretation too, and the archetypes were Franz Liszt and Arthur Rubinstein.

About musical interpretation, Alexandr Serov stated that reading of musical signs, the notes, didn't constitute the true musical interpretation. For a real interpretation, it is necessary to understand the sense of musical discourse and discern the secrets of musical poetics. The interpreter must be creative and capable to represent truthfully the content of musical work ${ }^{16}$.

This musical content that the creative musician embodies in his interpretation is imagined consciously or unconsciously. But this content is guided by the world view of the composer in the same process of musical creation. But, how is this process? It may be consciously or unconsciously too. Not many composers are described as their method of creation. And those that are described, recognized that they didn't know how it exactly happens. The first description of this process was related in an apocryphal letter attributed to Mozart, published in 1815 by Friedrich Johan Rochlitz in the Allgemeine Musikalische Zeitung of Leipzig17.

\footnotetext{
15 Ганслик, «0 прекрасномъ въ музыке» Предисловие отъ редакции.

${ }^{16}$ А. Серов. «Музыка и виртуозы» Критически статьи. Том первый (1851-1856 гг.) С. Петербург, 1892, с. 84-85.

${ }^{17} \mathrm{Cf}$. Friedrich Johan Rochlitz (Herausgeber). "Schreiben Mozarts an den Baron von...” Allgemeine Musikalische Zeitung, № 34, Der 23 sten August 1815. A M Z, Siebzehnten Jahrgang vom 4. Januar 1815 bis 27. Dezember 1815, S. 561-566.
} 


\section{Philosophy International Journal}

In another letter, sent to his patron Nadezhda von Meck the 1st March 1878 from Florence, Piotr Ilich Tchaikovsky describes the process of musical creation in his Fourth Symphony. He describes it as a lyrical process, like pure inspiration without any method. Moreover, he also describes the program of this instrumental work without a specific subject.

You asked me whether there is a definite programme to this symphony? Usually when this question is put to me about a symphonic work my answer is: none! Indeed, this is a difficult question to answer. How can one put into words the intangible sensations which one experiences when writing an instrumental work without a specific subject? This is a purely lyrical process. This is, fundamentally, an unburdening of the soul in music, with its essence distilled into sounds, in the same manner in which a lyrical poet expresses himself in verse. The only difference is that music has much more powerful means and a more subtle language with which to express thousands of different emotions and frames of mind. Usually the seed of a future work will manifest itself suddenly in unexpected ways. [...] Everything else happens by itself. It would be futile for me to try to express to you in words the immeasurable bliss of all the feelings that seize me when a main idea appears, and when it begins to flourish into a particular form. I forget everything and become literally like a madman, everything within me shakes and pulses, with barely time to scribble out my sketches as one idea runs into another... Sometimes in the midst of this magical process, some external stimulus will jolt me out of this somnambulistic state. [...] If the condition of the artist's soul called inspiration that I am attempting to describe to you were to be continued without interruption, it should be impossible to live for a single day. [...] Only one thing is necessary: that the principal idea and the general outlines of all the movements did not come about by striving, but rather that they present themselves as a result of that supernatural, incomprehensible, and unfathomable force that is called inspiration. But I have digressed on an aside without answering your question. In our symphony there is a programme, i.e. it is possible to express in words what it is trying to say, and to you, and only to you, I am able and willing to explain the meaning both of the whole and of the separate movements. Of course, I can do this only in general terms. The introduction is the seed of the whole symphony, undoubtedly the main idea:

This is Fate: this is that fateful force which prevents the impulse to happiness from attaining its goal, which jealousy ensures that peace and happiness shall not be complete and unclouded, which hangs above the head like the sword of Damocles, unwaveringly, constantly poisoning the soul. It is an invincible force that can never be overcome-merely endured, hopelessly.

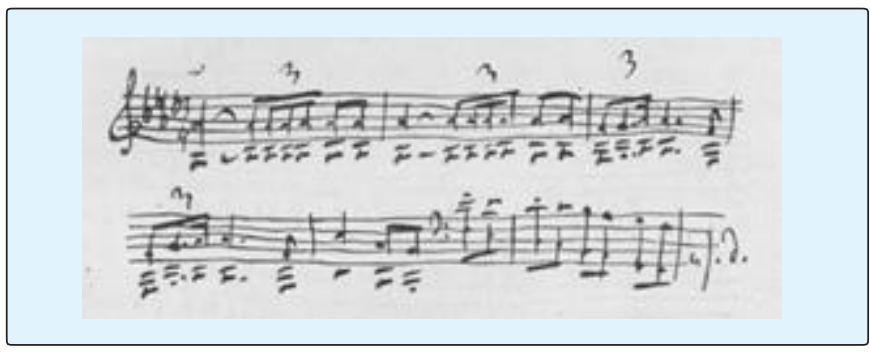

The bleak and hopeless feelings grow stronger and intense. Is it not better to escape from reality and to immerse oneself in dreams?

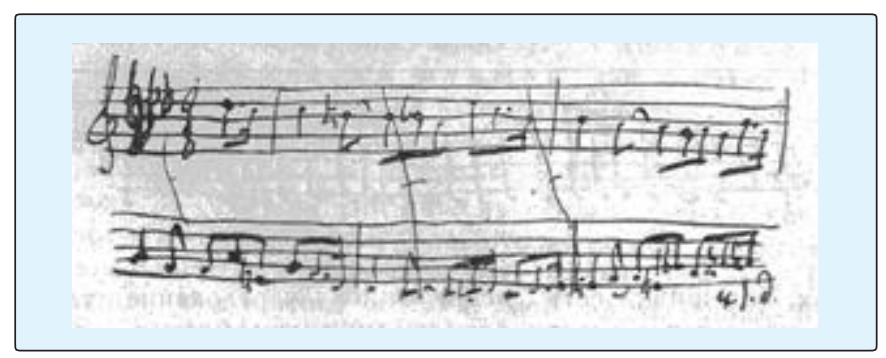

Oh joy! Out of nowhere a sweet and gentle day-dream appears. Some blissful, radiant human image hurries by and beckons us away:

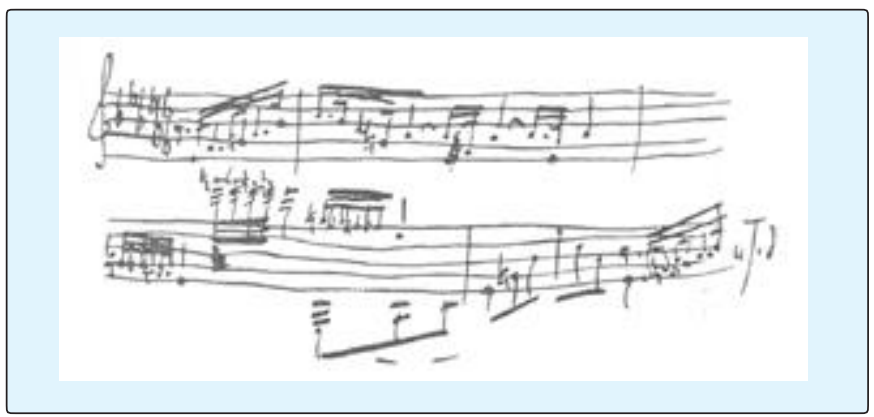

How wonderful! How distant the obsessive first theme of the allegro now sounds! Gradually the soul is enveloped by daydreams. Everything gloomy and joyless is forgotten. Here it is, here it is-happiness! No! These were daydreams, and Fate wakes us from them:

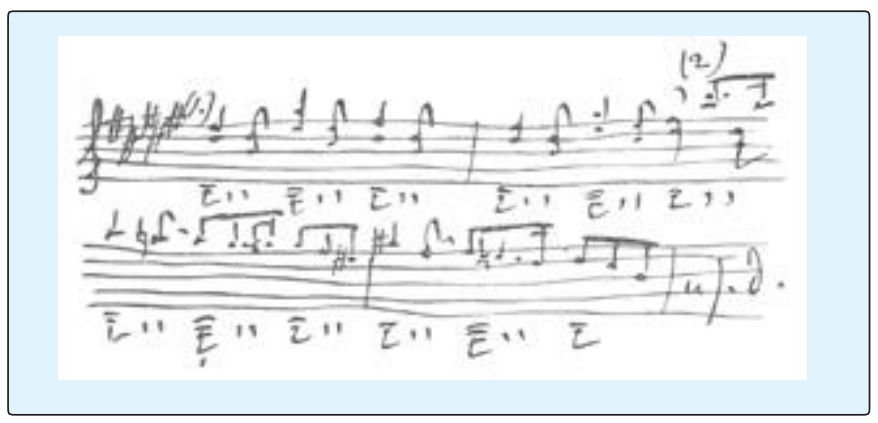




\section{Philosophy International Journal}

And thus all life is an unbroken alternation of harsh reality with fleeting dreams and visions of happiness... No haven exists... Drift upon that sea until it engulfs and submerges you in its depths. That, roughly, is the programme of the first movement.

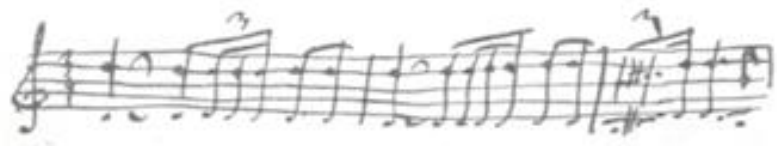

The second movement of the symphony expresses another aspect of sadness. This is that melancholy feeling which comes in the evening when, weary from one's toil, one sits alone with a book-but it falls from the hand. There come a whole host of memories. It is sad that so much is now in the past, albeit pleasant to recall one's youth. Both regretting the past, and yet not wishing to begin life over again. Life is wearisome. It is pleasant to rest and look around. Memories abound! Happy moments when the young blood boiled, and life was satisfying. There are also painful memories, irreconcilable losses. All this is now somewhere far distant. It is both sad, yet somehow sweet to be immersed in the past...

The third movement expresses no specific feeling. This is whimsical arabesques, vague images which can sweep past the imagination after drinking a little wine and feeling the first phases of intoxication. The spirit is neither cheerful, nor sad. Thinking about nothing in particular, giving free rein to the imagination, which somehow begins to paint strange pictures... Amid these memories there suddenly comes a picture of drunken peasants and a street song... Then, somewhere in the distance, a military procession passes. These are completely incoherent images which sweep through the head as one falls asleep. They have nothing in common with reality; they are strange, wild, and incoherent...

The fourth movement. If within yourself you find no reasons for joy, then look at others. Go out among the people. See how they can enjoy themselves, surrendering themselves wholeheartedly to joyful feelings. Picture the festive merriment of ordinary people. Hardly have you managed to forget yourself and to be carried away by the spectacle of the joys of others than irrepressible fate appears again and reminds you of yourself. But others do not care about you, and they have not noticed that you are solitary and sad. 0 , how they are enjoying themselves! How happy they are that all their feelings are simple and straightforward. Reproach yourself, and do not say that everything in this world is sad. Joy is a simple but powerful force. Rejoice in the rejoicing of others. To live is still possible.

That, my dear friend, is all I can explain to you about the symphony. Of course, this is vague and incomplete. But an intrinsic quality of instrumental music is that it does not yield to detailed analysis. Where words end, music begins, as Heine remarked ${ }^{18}$.

As we see, not only the program music has content, but the so call absolute music without a specific subject has too. Nevertheless, if the music has and communicates content or knowledge, what kind of knowledge it communicates? The answer to this question is that the music undoubtedly has and communicates knowledge but an artistic knowledge that differs from philosophical and scientific knowledge. The philosophical knowledge is expressed in abstract concepts, or in ideas that try to explain the world, just like scientific knowledge is expressed in laws that demonstrate the unit of Universe.

Arthur Schopenhauer sustained that in music we must see more than arithmetic operations, like the Pythagorean expression: exercitium arithmeticae occultum nescientis se numerare animi, which Gottfried Leibniz called it.

Yet he was perfectly right, as he considered only its immediate external significance, its form. But if it were nothing more, the satisfaction which it affords would be like that which we feel when a sum in arithmetic comes outright, and could not be that intense pleasure with which we see the deepest recesses of our nature find utterance. From our standpoint, therefore, at which the aesthetic effect is the criterion, we must attribute to music a far more serious and deep significance, connected with the inmost nature of the world and our own self, and in reference to which the arithmetical proportions, to which it may be reduced, are related, not as the thing signified, but merely as the sign ${ }^{19}$.

Therefore, Schopenhauer insists that if it is possible to reduce into concepts the essence of music, it will be a philosophy and not music. Music doesn't know how to philosophize.

\footnotetext{
18Письмо 763, в: П. И. Чайковский. Полное собрание сочинений. Том VII: Письма (1878). Москва, Государственное музыкальное издательство, 1962 (English translation by Galina von Meck. Letter 763, in: Nigel Gotteri, Eduard Garden (eds.) To my best friend: Correspondence between Tchaikovsky and Nadezhda von Meck, 1876-1878. Clarendon Press, 1993, pp. 183-188).

${ }^{19}$ Arthur Schopenhauer. The World as Will and Representation, Translated by Richard Burdon Haldane, World Heritage Encyclopedia, Second edition, 1844, Third book: The World as Idea Second Aspect, § 52, The music.
} 


\section{Philosophy International Journal}

Consequently, the saying of Leibnitz quoted above, which is quite accurate from a lower standpoint, maybe parodied in the following way to suit our higher view of music: Musica est exercitium metaphysices occultum nescientis se philosophari animi; for scire, to know, always means to have fixed in abstract concepts ${ }^{20}$.

Unlike the philosophical and scientific knowledge, artistic knowledge is expressed in artistic models or ideals. The artistic knowledge is expressed in a concrete subject, in a prototype that collects the most important characteristic of real subjects. This artistic model represents ideals such as the Beauty, the Sadness, the Hero, the Wood, the Evil, etc., etc. But these ideals are portraying in a concrete model and in a concrete artistic way.

Each art has its particular ways of representation and communication of the artistic models. In the case of music, its specific way is the intonation. The intonation portrays or recalls the artistic models, like happiness or melancholy and all diversity of states of consciousness.

From 1917 the soviet musicologist Boris Asaf'ev wrote several essays about intonation. In 1930 he published the first part of his Theory of Intonation, under the title: The musical form as a process. In his theory, Boris Asaf'ev stated that the musical forms are the result of social evolution. The musical form is not an empty form like a cage, or an abstract concept invented a priori by something, but the result of a social process.

Each musical form has its genesis and development, determined by the social conditions. The musical form is the result of the accumulation of intonations, that portray or recall the artistic models of the epoch. Every epoch has its artistic models diverted from the ideals of that historical phase. Therefore, when we conceive the musical form like an empty container, like an unfilled glass of wine, or like an academic schema that is perceived visually, appear the old parallelism between form and content.

In this research I try to link the development of resources of musical expression with the laws of human intonation like revelation of mind, with the musical tones in its diversity of unions and with the oral language. The thought, the intonation, the musical form, all this are in constantly relation. What the thought becomes a sonorous expression for, is necessary that it turns into intonation, to sing the thought ${ }^{21}$.

\footnotetext{
${ }^{20}$ Ibídem.

${ }^{21}$ Борис Асафьев. Музыкальная форма как процесс. Книга вторая. Интонация. Москва, Музгиз, 1947/ Книга первая и вторая (Интонация), Ленинград «Музыка», 1971, с. 211.
}

The musical intonation never lost its relation with the oral and gestural intonation (the dance). In the prehistory of mankind, the language and music were not separated. But the musical intonation, by intervals, emerged from a long social process of constant repetitions of the same rhythm-intonation. For a long time, this rhythmintonation had been repeated in magic formulas of enchantment in rites, rituals, or in the poetic declamation with its constant level of rhythm-intonation in the Theatre. These were the social phenomena that detached the first sonorous complex of musical intervals from the language. Just like in the oral language we can communicate by intonations all our emotions, in music the intonation evokes feelings, emotions and recalls a large number of states of consciousness too.

In fact, the notion of music like a language capable to communicates ideas, thoughts, knowledge, and even educates us, has more than two thousand years old, formulated in the theory of Ethos (character nं $\theta 0$ ) attributed to Damon of Athens ( $5^{\text {th }}$ BCE). This theory sustained the power of music to influence emotions, behaviors, and even morals. In the $17^{\text {th }}$ century appears Die Affektenlehre (Doctrine of the affections) of Johann Mattheson, which affirmed that some pieces or movements of instrumental music express Affekt or passion $^{22}$.

Like reaction to the rationalistic conception of music in the Enlightenment, in the $19^{\text {th }}$ century the romantic philosophes and composers like Lessing, Hegel, Schopenhauer, Liszt, Wagner, Tchaikovsky, etc., etc., gave back to the music in their writings the power of express and communicate ideas, thoughts, emotions, feelings, and knowledge.

The Kantian formal conception of music, that took up again Eduard Hanslick in his brief treatise of 1854, had a huge influence on the musical aesthetics and composition of the 20th century. Its aesthetic influence began with the Schonberg's atonalism of the Second Viennese School and continued with serialism, multi-serialism, integral serialism, and so on. These musical avant-gardes conceived the music only like an abstract combination of sounds without any relation with the social reality, rejecting any extra-musicological considerations.

Before the Second World War until the end of the Cold War, these two antagonistic conceptions of music became more radicals, involved in the ideological struggle

\footnotetext{
${ }^{22}$ Johann Mathesson. Der Vollkommene Kapellmeister. Hamburg,
} 1739. 


\section{Philosophy International Journal}

between East and West. A struggle between the Marxist musical aesthetics of 'art-as-politics' versus the 'aesthetic autonomy' of Kantian-Hanslickian formalism.

Since 1933 many soviet musicologists wrote in the journal Sovetskaya Muzyka about the 'bourgeois' decadent formalism in Europe, like the article of A. Alshvang 'The ideological path of Stravinsky'. ${ }^{23}$ After the Second World War, the Asaf'ev Theory of Intonation was taking as the musicological basis to the Marxist aesthetics, that held the Gorky's theory of Socialist Realism in the Soviet Union during the Zhdanovism [Ждановщина] in 1948.

But Marxist musicology offered an alternative to positivism, rejecting the notion of artistic autonomy and theorizing music as social discourse. The East musicology was focused on theory and method, and many works were done in music psychology, perception, cognition, and semiotics. The musicologists of socialist countries were concerned with the need to find out how music communicates, what is communicated and for what purpose. Finally, how the 'message' of work changes, if it does, over time.

The most urgent task for Marxist music historians was to reconnect music with society. If you believe that music as a human product is primarily a system of communication and a social practice (although one with a strong aesthetic component), then you will not be satisfied with a historical account that treats the internal logic of styles and genres, nor with one that presents a parade of great composers and their works disconnected from their social contexts. You will need to find out how music communicates, between which people and in what contexts, how it did so in the past, what is communicated and for what purpose, and finally how the "message" of a work changes, if it does, over time. There can be no completely autonomous music in this scheme ${ }^{24}$.

In 1962 the Hungarian musicologist József Ujfalussy published The Musical Image of Reality. Logic of the Meaning of Musical Art ${ }^{25}$. Following the Asaf'ev Theory of Intonation, J. Ujfalussy affirms that the objective sources of music are the human activity expressed in 'intonations'. One particular contribution to the Asaf'ev theory is the relation between music and movement, and his

\footnotetext{
${ }^{23}$ Арнольд А. Альшванг «Идейный путь Стравинского» Советская Музыка, 1933, № 5, с. 90-101.

${ }^{24}$ Anne C. Shreffler. "Berlin Walls: Dahlhaus, Knepler, and Ideologies of Music History" The Journal of Musicology, Vo. 20, № 4 (Fall 2003): 498-525, p. 504.

${ }^{25}$ József Ujfalussy. A valóság zenei képe. A zene művészi jelentésének logikája; Zenemúkiadó Vállalat, Budapest, 1962.
}

demonstration of the spatial character of the musical image.

In the same expressions like 'art in the time' or 'art in the space' there is a contradiction (contradiction in adiecto), because the art is an artistic generalization by means of models, and not of concepts. Consequently, it [the art] not addresses to the abstract mind in concepts, but to the model perception. Space and Time are categories of the existence and contemplation too, which we can observe in our consciousness separated each other thanks to any scientific research, though separately perceive or contemplate it, hardly somebody can do it to date. Subsequently, speaking about the artistic model like a replication of reality, we can only consider the model that in our consciousness forms the inseparable unit of two fundamental categories of the existence ${ }^{26}$.

The most important for Marxist musicology was considered music like a social phenomenon, and not just schematic reductions in musical notation. How music can mean and communicate, and this, in turn, will help us to understand the essence of human communication in general. The musical expression is as fundamental to human communication as is language. Since human beings have 'used' music at every stage in their history, music has played a role in forming human consciousness.

The development of music depends on historical and social factors. These social conditions are in no sense background, external events, but rather constitutive ones for all aspects of life, including artistic expression. The dialectical relationship between music and society continually shape and reflect each other. The power of music affects the human being. This expressive power is communicative, as such is inextricable from its social function.

Just like in the Asaf'ev Theory of Intonation, for the East German musicologist Georg Knepler, in prehistoric societies music served as a complementary alternative to language; one allowed the communication of extreme and unformed emotion (music) while the other allowed formulation of precise ideas (language) ${ }^{27}$.

The close link between music and language has been maintained throughout history. Musical material has been

\footnotetext{
26Йожеф Уйфалуши. Единство пространства, времени и действия. О содержании музыкального образа. в сборнике «Музыка Венгрии», Москва, «Музыка» 1968, с. 190.

${ }^{27}$ Georg Knepler. Geschichte als Weg zum Musikverständnis: Zur Theorie, Methode und Geschichte der Musikgeschichtsschreibung. Leipzig: Reclam, 1977, S. 36-37.
} 
shaped over the eons in specially coded ways, each appropriate for its particular social environment, in order to heighten music's communicative power. Even 'art music', which developed much later, still carries the vestiges of the primeval yells and sighs of prehistoric music ${ }^{28}$.

At the same time, in opposition to Marxist musicology, the aesthetic criteria in the musical analysis and documentary studies of West-European and AngloAmerican musicology, with its emphasis on musical positivism, rejected all extra-musical meanings in a work.

[...] musicology in West Germany in the Cold War years can be understood as identifying certain modes of thought (such as socio-political readings of musical work) as extra-musicological and thereby outside the concern of musicological discussion. In this climate, music was considered to be a "socially functionless, nonauthoritarian discourse." East German musicology during this period can be understood as "theorizing music as social discourse" 29 .

Since the mid $19^{\text {th }}$ century, music scholarship attempted to separate music from its semantic, communicative function and to replace it with a purely 'syntactic' one. A pure analysis of 'the notes'. From Hanslick to Riemann, many theorists have sought to reduce the content of the music to the relationship between notes, labeling its expressive content as something external.

Knepler believes that to deny music's communicative, semantic function means to exclude its emotional impact and correspondingly, its aesthetic value. [...] The conceptual separation of music's syntactical elements from its capacity to express emotive meaning is an unfortunate development in music scholarship. ${ }^{30}$

Towards the end of the Cold War, these antagonistic musical conceptions come closer, thanks to the hermeneutical and semiotic studies that anticipates some of the main tenets of the 'New Musicology'. The thaw of this 'musicological cold war' initiates whit the West German musicologist Carl Dahlhaus, which begins a dialogue with 'extra-musicological' aspects that came from materialist-sociological Marxism and empirical-

\footnotetext{
${ }^{28}$ Shreffler, "Berlin Walls" p. 513.

${ }^{29}$ Nicole Grimes, Siobhán Donovan \& Wolfgang Marx. Rethinking Hanslick. Music, Formalism, and Expression. Rochester, University of Rochester Press, 2013, p. 3.

${ }^{30}$ Shreffler, "Berlin Walls" p. 514.
}

hermeneutic phenomenology, like a viable alternative to Marxist theory. Nevertheless, Dahlhaus was focused around music as autonomous work, and pointed out that a musical artwork itself claims to be considered as art. "At the heart of the Dahlhaus project was an effort to keep the Austro-German cannon from Beethoven to Schoenberg free from aggressively socio-political interpretations"31.

In "Issues in Composition" Dahlhaus writes:

That there are social implications in the works themselves, in the very conception of the Ring and in the idea of absolute music embodied in the string quartet, cannot seriously de denied, although the prospect of deciphering them is one to daunt any scholar whose ambitions go beyond facile categorization (such as 'bourgeois culture') [...] The fundamental rule of hermeneutics [... in the] interpretation of one particular phenomenon; in any event, the assumption that the context of musical works is always society as a whole is an exaggeration, dogmatic in origin ${ }^{32}$.

With the end of the Cold War in 1989 came the translation of much of Dahlhaus output into English, and the establishment of the field of 'New Musicology' in West Europe and North America. In 2013 was published in the United States the book: Rethinking Hanslick: Music, Formalism, and Expression, which introduces a paradigm shift to Hanslick studies, dedicated to a reevaluation of his musical formalism ${ }^{33}$.

More recently, in 2019 was published Re-Reading Hanslick's Aesthetics in Wien, a book written in German about the reception of Vom Musikalisch-Schönen in the English-speaking world, and its discursive fundaments ${ }^{34}$.

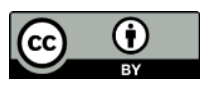

\footnotetext{
31James Hepokoski. "The Dahlhaus Project and Its ExtraMusicological Sources" 19th-Century Music, Vol. 14, № 3 (Spring, 1991), pp. 222.

${ }^{32}$ Carl Dahlhaus. "Issues in Composition" in: Between Romanticism and Modernism: Four Studies in the Music of the Later Nineteenth Century. Translated by Mary Whitall. Berkeley: University of California Press, 1980, p. 77.

${ }^{33}$ Cf. Nicole Grimes, Siobhán Donovan \& Wolfgang Marx. Rethinking Hanslick. Music, Formalism, and Expression. Rochester, University of Rochester Press, 2013.

${ }^{34}$ Alexander Wilfing (ed.). Re-Reading Hanslick's Aesthetics. Die Rezeption Eduards Hanslicks im englischen Sprachraum und ihre diskursiven Grundlagen. Wiener Veröffentlichungen zur Musikwissenschaft, Wien, Hollitzer, 2019.
} 